\title{
A rare synchronous tumor: primary squamous cell lung cancer and adenoid cystic carcinoma of the tongue
}

\author{
Gülistan KARADENiZ ${ }^{1}$ \\ Zehra YAŞAR ${ }^{2}$ \\ Fatma ÜÇSULAR ${ }^{1}$ \\ Gülcan ÜRPEK ${ }^{1}$ \\ Melih BÜYÜKŞiRIN ${ }^{1}$
}

${ }^{1}$ Clinic of Chest Diseases, Dr. Suat Seren Chest Diseases and Chest Surgery Training and Research Hospital, Izmir, Turkey

${ }^{1}$ Dr. Suat Seren Göğüs Hastalıkları ve Cerrahisi Eğitim ve Araştırma Hastanesi, Göğüs Hastalıkları Kliniği, İzmir, Türkiye

${ }^{2}$ Clinic of Chest Diseases, Medistate Kavacık Hospital, Istanbul, Turkey

${ }^{2}$ Medistate Kavacık Hastanesi, Göğ̈̈s Hastalıkları Kliniği, Istanbul, Turkey

\section{SUMMARY}

A rare synchronous tumor: primary squamous cell lung cancer and adenoid cystic carcinoma of the tongue

Persence of multipl primary tumors in an organism is called as multiple primary cancer (MPC). Multipl tumors that occur at the same time are synchronized tumors, while those occuring at the different times called metachronous. MPCs are very rare entities. Here in we report a 96-year-old man who presented with synchronous MPC including squamous cell Lung cancer and tongue adenoid cystic carcinoma.

Key words: Multiple primary cancer, lung cancer, tongue, adenoid cystic carcinoma

\section{ÖZET}

Nadir senkron tümör: Skuamöz hücreli akciğer kanseri ve dilin adenoid kistik karsinomu

Bir hastada aynı zamanda birden fazla farklı odakta primer kanser bulunmasına multipl primer kanser denir. Multipl primer kanser, eş zamanlı bulunuyorsa senkron, farklı zamanlarda oluşmuşsa metakron olarak tanımlanır. Senkron tümörler metakron tümörlere oranla daha seyrek görülmekte olup prognozları daha kötüdür. Skuamöz hücreli akciğer kanseri ve dilin adenoid kistik karsinoması olarak tanı alan senkron multipl primer kanser ile başvuran 96 yaşında bir erkek hasta nadir görülen bir durum olması nedeniyle sunulmuştur

Anahtar kelimeler: Multipl primer kanser, akciğer kanseri, dilin adenoid kistik karsinom

\section{Yazışma Adresi (Address for Correspondence)}

Dr. Zehra YAŞAR

Medistate Kavacık Hastanesi, Göğüs Hastalıkları Kliniği, iSTANBUL-TURKEY

e-mail: zehraasuk@hotmail.com 


\section{INTRODUCTION}

Multiple primary cancers (MPC) are very rare entities that defined as persence of two or moretumors in an organism. If two different primary cancers diagnosed at the same time or in short intervals called synchronus, and if second tumor is diagnosed after 24 months of diagnosis ofprimary tumor called as metachronous cancers. The most common secondary primary tumors settles in the lung $(27.6 \%)$, head and neck $(20.3 \%)$ and urinary tract $(10.4 \%)$. And all of these tumors are associated with smoking and it depends on the affects of tobacco smoke to different regions of the epithelium $(1,2)$.

Oral cavity tumors which constitutes $4 \%$ of head and neck tumors suggests a parallel increase with tobacco and alcohol consumption. Although the squamous cell cancers are most commonly seen, minor salivary gland carcinomas of the oral cavity are uncommon tumors. Minor salivary gland cancers most commonly occur in the hard palate. Minor salivary gland tumors of the tongue root are rarely seen and nearly all were malignant.

Here, we report on the case of a patient with synchronous tumor because of its rarity. Andalso adenoid cystic carcinoma of the tongue seen very rare. To our knowledge, there is no report in medical literature which describe this combined entity.

\section{CASE REPORT}

A 96-year-old male patient was admitted to our hospital with the complaints of a hoarseness, weight loss, chest pain, shortness of breath, difficulty swallowing and fullness in the mouth for two months. His past medical and family history was unremarkable. He has a history of 80 packs-year smoking. His physical examination was as follows: body temperature $37^{\circ} \mathrm{C}$, arterial blood pressure $110 / 70 \mathrm{mmHg}$, heart rate 100 beats/min, respiratory rate 16 breaths/min. He seemed weak, pale and dehydrated. In the rear section of the tangue was asymmetric (more pronounced on the left than the right side). Lung sounds were decreased on auscultation.

The sputum investigations for ARB were negative. Chest X-Ray showed reticulary dansities on the right upper and middle lobe. In the thorax CT, mediastinal lymphadenopathy, endobronchial mass that in the right upper lobe bronchus moving towards to the main bronchus and lesions in the both hemithoraxes which were found to be attributable to metastasis (Figure 1A). A computed tomography (CT) scan of the neck showed the dominant portion of the mass measured up $7 \times 8 \mathrm{~cm}$ covering left side of tangue that made destruction on the anterior left side of maxilla and this narrows air gap asymmetrically in the posterior part of the oropharynx (Figure 1B). Fiberoptic bronchoscopy showed a mass that obstructed the right main bronchus and multiple biopsy was carried out from endobronchial lesion. Pathological examination of the specimen was reported as a non-small cell carcinoma (squamous cell) (Figure 1C). The immune histochemistry applied for the separation of primary and metastatic tumor. The histopathologic findings were supporting primary lung cancer. The wedge biopsy was taken from the left lateral part of the tangue and punch biopsy was taken from the deep parts. Cytopathologic evaluation of the biopsies revealed as adenoid cystic carcinoma (Figure 1D). Systemic screening showed no other organ involvement. Our case was considered to be a synchronous squamous cell cell lung cancer (T3N2M1) and adenoid cystic carcinoma of tangue. Airway obstruction threated with APC and electrocoter by rigid bronchoscopy. After the removal of the debris lumen patency were obtained nearly $60 \%$. Palliative radiotherapy was given for carcinoma of the tangue.

\section{DISCUSSION}

The criteria defined by Martini and Antakli are used to divide the tumors as synchronous and metachronous (1-4). If tumors are present at the same time, they must be separated and the histology must be different. If both tumors have the same histology, they are located in different lungs, lobes, segments or organs, they have no common lymphatics, and there are no distant metastases present, they are considered to be two independent primary tumors (4). In our case, two different histological types of carcinoma in individual organs diagnosed at same time considered as synchronous tumors. An important theory often used to explain multiple malignancies is the "field cancerization theory," which states that organ systems exposed to the same carcinogenic agents have agreater chance of transforming into a malignancy. For example smoking plays an important role as a carcinogenic agent in the etiology of malignancies at lung, head and neck cancer and/or cancer of the bladder $(1,5)$. In addition, this hypothesis clarifies the 
reason of the association of this region in multiple primary cancer. After all, smoking history in our case considered as the common etiological factors for cancer of the lung and tangue.

In many sources, when more than one primary tumor (synchronous or metachronous) occurs in the same patient, the most common histologic type is squamous cell cancer. Especially if the first primary malignancy origin from mouth, second primary malignancy is likely to be squamous cell cancer in upper respiratory tract, upper digestive tract and in the lung (6). Lung malignancies developed after primary head and neck cancers are likely to be squamous cell carsinoma nearly up to $90 \%$ (6). In our case, adenoid cystic carcinoma of tongue is accompanied by squamous cell carcinoma of the lung.

In multiple primary tumors, cancers are staging individually and high-grade tumors determines the prognosis. Surgery is the standard option when feasible in multiple primary cancers (1-8). In our case endobronchial therapy for airway obstruction and palliative radiotherapy for tongue performed because of poor performance and advanced stage of cancers.

In conclusion, the incidence of synchronous cancers are increased because of the reduced mortality resulting from improved treatments and the development of advanced tools for the early detection of cancerous lesions. When the first primary cancer is found, we should focus on both the staging as well as on the detection of other related tumors. If suspicious lesions are found, further examination like biopsy can be reduced the probability of misdiagnosis and rule out metastatic lesions. Early diagnosis and appropriate treatment improves patient survival.

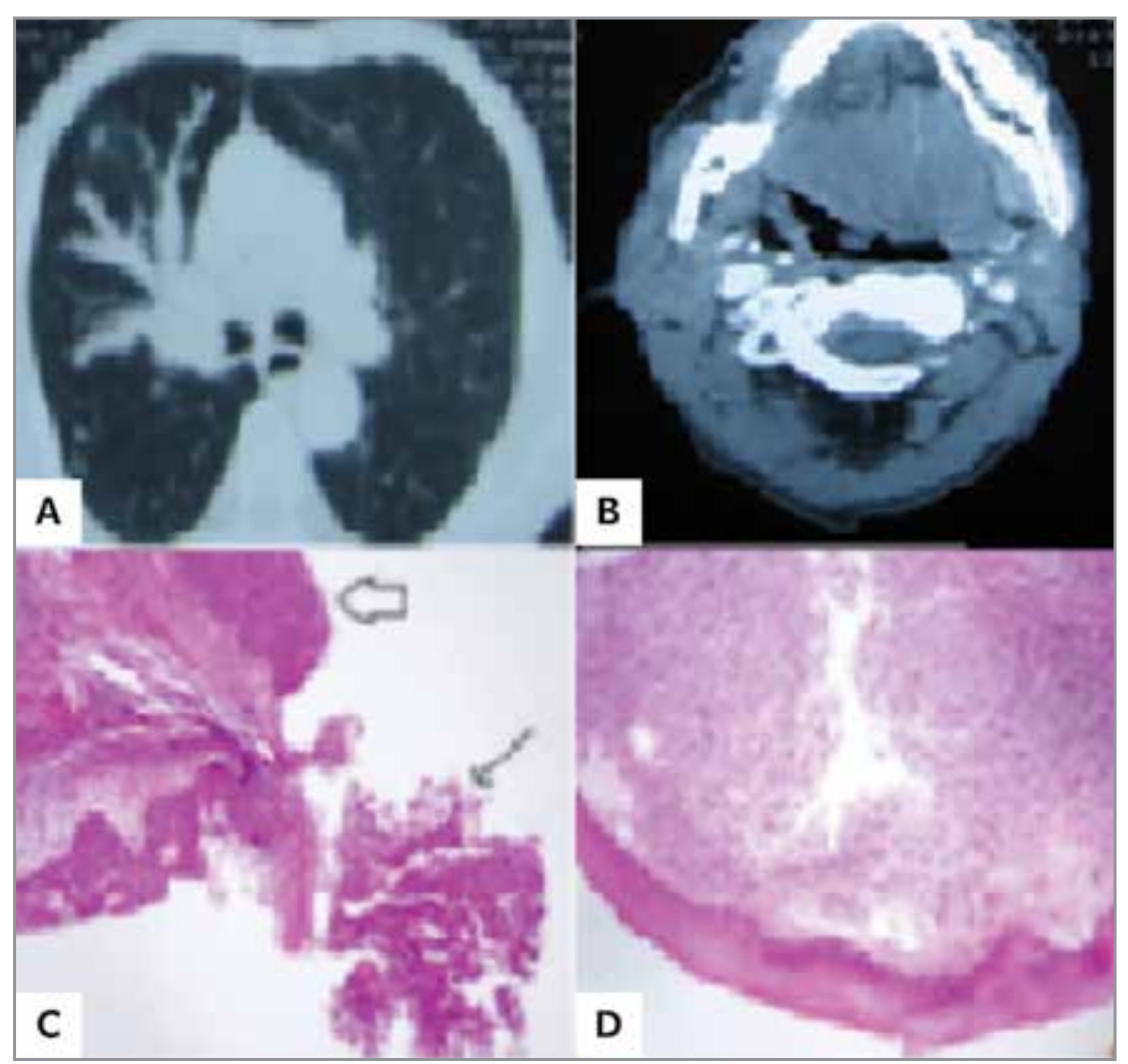

Figure 1. (A) Chest CT scan showing endobronchial mass in the right upper lobe bronchus. (B) Neck CT scan showing dominant part of mass covering left side of tangue and narrowing air gap asymmetrically. (C) The focus of squamous carcinoma in situ developed from possible metaplastic bronchial mucosa (thick arrow) and invasive squamous cell carcinoma (thin arrow). (D) The tongue tissue which covered by stratified squamous epithelium, tumor (adenoid cystic carcinoma) infiltration consist of small spaces and cords in large areas $(\mathrm{H} / \mathrm{E}, 40 \mathrm{X})$. 


\section{REFERENCES}

1. Duchateau CS, Stokkel MP. Second primary tumors involving non-small cell lung cancer:prevalence and its influence on survival. Chest 2005;127:1152-8.

2. Trousse D, Barlesi F, Loundou A, Tasei AM, Doddoli C, Giudicelli $R$, et al. Synchronous multipleprimary lung cancer: an increasing clinical occurrence requiring multidisciplinary management. T Thorac Cardiovasc Surg. 2007; 133:1193-200.

3. Martini N, Melamed MR. Multiple primary lung cancers. The Journal of thoracic and cardiovascular surgery. 1975;70:606-12.

4. Antakli T, Schaefer RF, Rutherford JE, Read RC. Second primary lung cancer. Ann Thorac Surg 1995;59:863-6.
5. Teppo L, Salminen E, Pukkala E. Risk of a new primary cancer among patients with lung cancer of different histological types. Eur J Cancer (Oxford, England: 1990). 2001;37:613-9.

6. Fraser RS CN, Müller NL, Pare PD. Fraser et Pare's diagnosis of disease of the chest. $2^{\text {nd }}$ ed. Philadelphia: WB Saunders Company, 1999:1201.

7. Adebonojo SA, Moritz DM, Danby CA. The results of modern surgical therapy for multipleprimary lung cancers. Chest 1997;112:693-701.

8. Braakhuis BJ, Tabor MP, Kummer JA, Leemans CR, Brakenhoff RH. A genetic explanation ofSlaughter's concept of field cancerization: evidence and clinical implications. Cancer Res 2003;63:1727-30. 